\title{
Analyzing Renewable and Nonrenewable Energy Sources for Environmental Quality: Dynamic Investigation in Developing Countries
}

\author{
Itbar Khan $\mathbb{D}^{1},{ }^{1}$ Lei Han $\mathbb{D}^{1},{ }^{1}$ Hayat Khan $\mathbb{D}^{2},{ }^{2}$ and Le Thi Kim Oanh $\mathbb{D}^{3}$ \\ ${ }^{1}$ Business School of Xiangtan University, Xiangtan, Hunan, China \\ ${ }^{2}$ China Center for Special Economic Zone Research, Shenzhen University, Shenzhen, China \\ ${ }^{3}$ College of International Education, Guangxi University for Nationalities, Guangxi, Nanning, China
}

Correspondence should be addressed to Hayat Khan; khiljihayat@gmail.com

Received 29 June 2021; Revised 16 August 2021; Accepted 30 August 2021; Published 21 September 2021

Academic Editor: Mojtaba Nasiri

Copyright (c) 2021 Itbar Khan et al. This is an open access article distributed under the Creative Commons Attribution License, which permits unrestricted use, distribution, and reproduction in any medium, provided the original work is properly cited.

Most of developing countries are facing environmental degradation challenges as these countries use energy from fossil fuels to enhance economic activities and that leads to environmental degradation. The use of renewable energy is required to mitigate environmental degradation; however, developing countries may not yet have reached the desired level to acquire renewable energy. It is important for developing countries to make polices to shift from nonrenewable energy to renewable energy use to protect environmental quality. In this regard, the importance of different energy sources and financial development in enhancing environmental quality in 21 developing countries is examined from 1970 to 2018 . The study employed dynamic estimator, and the results indicate that the sources of renewable energy enhance environmental quality as compared to nonrenewable energy and its sources. Financial development also lowers environmental quality in our results. The study recommends reducing carbon emissions by reducing the use of fossil fuel energy and acquiring new technologies, attracting foreign investors in clean energy that provide clean technologies for green production, and investing in renewable energy sources to evade nonrenewable energy. Policy makers should adopt environmentally-friendly strategies and equipment to protect environmental quality, while striving for achieving economic growth.

\section{Introduction}

Developing countries are trying to raise the level of economic growth and development by establishing policies which are helpful to increase the investment level. An economy can grow if it is enough developed financially. Financial institutions are important for a country to enhance investment by providing credit facilities and provide opportunities of capital. Financial development promotes the energy sector which accelerates economic activities [1]. Energy consumption also plays an important role to enhance economic growth by facilitating production with capital and labor. Both financial development and energy consumption promote production levels and economic growth, but they increase carbon emissions and cause environmental degradation [2]. The use of energy is important to promote economic activity, and it also creates environmental-related problems, such as the depletion of natural resources and carbon emissions. In this context, developing countries urgently need to promote economic growth. Therefore, for decades, they have widely used fossil fuel energy to promote economic and developmental activities. The reason of environmental degradation faced by developing countries is the reason of energy from fossil fuels being used to increase economic activities. Increasing these activities for the purpose to enhance economic growth in developing countries is important; however, the quality of environment also needs to be protected. In such cases, fossil fuels are used in industries to enhance economic growth, which leads to degrading of the environment as industries have high demand for energy and thus use fossil fuels to meets their increasing demand. Wolde-Rufael and Menyah [3] argue 
that environmental degradation is the reason of nonrenewable energy use as it releases high amount of carbon dioxide. The use of renewable energy sources that includes wind, hydro, and solar can be the substitute to overcome such environmental issues. The use of renewable energy can fulfil the production requirement for energy and enhance environmental quality as well as it does not cause pollution by replacing nonrenewable technologies and does not degrade environmental quality $[4,5]$. On the contrary, some studies suspect the role of renewable energy in environment protection such as Jebli and Yossef [6] claim that waste and combustible renewables are not clean energy and the use of combustible renewables and wastes increases emission. However, the theoretical literature considers that renewable energy consumption is beneficial for environment quality; however, some studies have given mixed results. Some studies indicate that renewable energy usage reduces carbon emission such as [5,7-13], while some studies argue that renewable energy usage increases emission such as [14-16]. On the other side, some of the previous studies claim that there is no effect or insignificant impact of renewable energy on carbon emission [17]. Developing countries should especially focus to make polices and convert from nonrenewable sources of energy and invest in projects to convert to renewable energy. Financial sector contribution is also important to fund green energy projects to facilitate renewable energy. The developing countries' financial development can enhance the renewable energy if it is well developed. The improvement in financial sectors and energy in turn keeps enhancing the level of economic growth as well can achieve higher environmental quality in developing countries. Based on the ongoing debate on the role of renewable and nonrenewable energy sources usage in carbon emission and considering environmental degradation as a global challenge for countries, especially for developing countries, requires empirical research and policy implications. The current study, therefore, examines both renewable and nonrenewable energy and its sources on carbon emission to identify the contribution of each energy sources to environmental quality. The focus of the study is to determine that whether conversion from nonrenewable energy to renewable energy may significantly improve the environmental quality of the sample countries. In our research, we also pay attention to the impact of financial development on carbon emissions. The developed financial system can promote renewable energy projects. Green finance can help improve the quality of the environment. However, if financial development does not fund renewable energy projects, finance will cause environmental degradation. The study used the latest data downloaded from BP statistics and World Development Indicators between 1970 and 2018. This study implemented static and dynamic models including OLS, FE, and SGMM and examined the impact of energy use on carbon emissions in developing countries. Based on the above discussion, this research is very important for developing countries to obtain advice when using nonrenewable energy to promote their economic growth. The study was implemented for the first time and provided very useful suggestions for the sample countries to invest in renewable energy projects to meet the energy needs of production and achieve higher environmental quality. It is better to invest in the energy sector than to focus solely on economic growth because in the long run, investing in renewable energy projects can bring double benefits, economic growth and environmental quality. Our results confirm that the use of nonrenewable energy sources for production in developing countries leads to degradation of the environment, while renewable energy sources are the safeguard of environmental quality. Financial development in the sample countries has also been found a weak determinant to enhance environmental quality which needs attention. The countries should strengthen financial institutions to fund renewable energy projects.

The rest of the paper is structured in the given sequence. Section 2 is composed of related literature, Section 3 presents the study methodology, Section 4 is composed of empirical results and discussion, while Section 5 gives the conclusion and policy implication.

\section{Literature Review}

A large number of existing studies uses panel and time series data and conduct research studies on the impact of the use of renewable and nonrenewable energy on environmental quality in samples of different countries and regions and have achieved different results. For example, Zaidi et al. [18] examined carbon emission and renewable and nonrenewable energy in Pakistan. They used ARDL estimator and found insignificant effect of renewable energy while positive effect of nonrenewable energy on carbon emission. In case of sub-Saharan Africa, Hanif [19] investigated the same association and found that the influence of renewable energy is smaller on carbon emission. Similarly, in [20], the authors studied energy use and carbon emissions from 1980 to 2015 and found that the impact of natural gas and oil on carbon emissions is asymmetric. They further discovered that the impact of nonrenewable energy on carbon emissions varies from country to country. Khan et al. [21] studied the impact of energy consumption on carbon emissions from 1965 to 2015 and found that there is a short-term and long-term relationship between variables and carbon emissions. They believe that renewable energy usage reduces carbon emissions. In the United States, Ongan et al. [22] studied the impact of renewable energy and fossil fuels on carbon emissions. They proved the EKC hypothesis in their findings and pointed out that fossil fuels have a negative impact on Texas' carbon emissions, while energy consumption increases Florida's emissions. Anser et al. [23] studied renewable and fossil fuels energy along industrial growth on carbon emission in Caribbean and Latin America for the year 1990 to 2015. They used the two-step system GMM model and found the inverted U-shaped relationship of carbon emission and economic growth which is evident in EKC hypothesis. They further found that industrial growth and fossil fuels' energy increase carbon emission. Zhao et al. [24] investigated the effect of energy consumption and geopolitical risk on carbon 
emission in BRICS countries. They used the ARDL method and found that geopolitical risk negatively affects energy consumption in some countries as well carbon emission in few countries. They further state that a decrease in geopolitical risk negatively and positively affects carbon emission in different countries of BRICS. Karimi et al. [25] studied the association of renewable energy, economic growth, and carbon emission in Iran for the period of 1975 to 2017. They used cointegration and asymmetric method where the findings indicate that renewable energy use and carbon emission increase economic growth in the long run, while decrease in renewable energy also has the same effect; however, economic growth strongly increases renewable energy. They further found that carbon emission has insignificant impact on economic growth. Yuping et al. [26] studied the effect of renewable and nonrenewable energy use and globalization on carbon emission in Argentina from 1970 to 2018. They used the ARDL model and found that globalization and renewable energy consumption reduce, while nonrenewable energy increases emission in short as well in the long run. On the contrary, Majeed and Luni [27] used panel data from 166 countries to study the impact of water withdrawal, energy use, and economic growth on carbon emissions. Their research period was 1990-2017, and they used two-stage least squares and fixed and random effects' models. They found that the use of renewable energy had a negative impact on emissions and that water intake would increase emissions. They further proved the EKC hypothesis. Khan et al. [28] studied the impact of foreign direct investment on carbon emissions in developing and developing countries. Using long-term estimates and static and dynamic models, they found that the impact of trade openness on carbon emissions in developing countries is diminishing, while the impact of trade on carbon emissions in developing countries is the opposite. They further formulated regulations for renewable energy to reduce emissions in developed and developing countries. Likewise, in [29], the authors believe that it is difficult for developing countries to switch from fossil fuels to renewable energy, and because the economic and technological level and energy structure are different in developing and developed countries, the transition from developing countries to renewable energy is a challenge. Similarly, Khan et al. [28] studied trade, foreign direct investment, and carbon emissions in developing countries. Using static, dynamic, and long-term estimates, they found that open trade and renewable energy use reduced carbon emissions in developing countries. They also pointed out that foreign direct investment has increased emissions in developed countries, while reducing emissions in developing countries. Similarly, in [29], the authors believe that it is a challenge for developing countries to switch from fossil fuel energy to renewable energy use. Due to different economic and technological conditions, the energy structure of developing countries and developed countries is different, which is why it is difficult for developing countries to switch to renewable energy. Ali et al. [30] investigated the impact of Pakistan's energy consumption, financial development, and trade on carbon emissions from
1980 to 2015. Applying ADF testing and ARDL to the data, it is found that the influence of research variables is increasing with regard to carbon emissions. For a summary of the relevant literature on the impact of renewable energy and nonrenewable energy consumption on carbon emissions, detailed information is given in Table 1 below.

On the contrary, Khan et al. [43] examined energy consumption, the inflow of foreign direct investment, and carbon emissions in the global countries. They found the interinfluence of these variables on each other, while the consumption of renewable energy has reduced carbon emissions and, at the same time, reduced the inflow of FDI. They found that FDI promotes economic growth, while the use of renewable energy reduces economic growth. However, as Khan et al. [44] pointed out by studying the impact of FDI inflows in Pakistan on governance, the increase in FDI is the cause of good governance. They found that governance indicators are important to the increase in FDI inflows. Cetin et al. [45] examined trade openness, economic growth, and energy consumption in Turkey. Their study time period was from 1960 to 2013, and they found that trade, energy consumption, and financial development have long-run association.

Likewise, Dogan and Ozturk [8] investigated carbon emission and nonrenewable and renewable energy in US for the time 1980 to 2014 . They found the existence of cointegration of the study variables, while the ARDL results show that carbon emission is reduced by the use of renewable energy, while increased by nonrenewable energy use. However, they found that the EKC assumption is invalid for the United States of America. Khan et al. [46] studied trade, quality institutions, and innovation of global carbon emissions. They found that open trade and FDI reduced carbon emissions, where the impact of institutional quality indicators was significant for carbon emissions. They further found the increasing influence of innovation in emission. Similarly, Bhat [47] studied the carbon emissions of renewable and nonrenewable energy in a sample of five emerging countries from 1992 to 2016. They employed the panel model and found that capital and labor were positively correlated in long run with nonrenewable energy; however, the impact of renewable energy on carbon emissions was insignificant. Similarly, Khan et al. [48] studied the relationship between environmental factors in the global panel by considering the technological progress and institutional quality in the association. They used static and dynamic GMM to discover the positive impact of technology progress, financial development, and the use of nonrenewable energy on carbon emissions, while the negative impact of renewable energy and FDI on carbon emissions. However, in their research results, the impact of institutions on carbon emissions is negative. Ito [9] studied carbon emissions, renewable energy consumption, nonrenewable energy consumption, and economic growth and found that the consumption of nonrenewable energy has a negative impact on economic growth, while the consumption of renewable energy has a positive impact on the economic growth of developing countries. 
TABLE 1: Summary of literature.

\begin{tabular}{|c|c|c|c|c|}
\hline Study & Time & Main variables & Countries & Methodology \\
\hline Alqaralleh [31] & $2000-2018$ & $\begin{array}{l}\mathrm{CO} 2 \text {, GDPPC, RE, NRE, and } \\
\text { POP }\end{array}$ & $\begin{array}{l}30 \text { European } \\
\text { countries }\end{array}$ & Panel smooth transition regression \\
\hline Fatima et al. [32] & $1998-2014$ & $\begin{array}{l}\text { GDPPC (per capita GDP), } \\
\text { RE, NRE, TO, and CO2 }\end{array}$ & $\begin{array}{l}\text { High emitter } \\
\text { countries }\end{array}$ & $\begin{array}{c}\text { Kao cointegration, GMM, and random and } \\
\text { fixed effect }\end{array}$ \\
\hline $\begin{array}{l}\text { Ibrahim and Ajide } \\
\text { [33] }\end{array}$ & $1990-2018$ & Coal, gas, fuel, TO, and CO2 & G-20 countries & $\begin{array}{c}\text { Augmented mean group (AMG), common } \\
\text { correlated effect mean group (CCEMG), and } \\
\text { mean group }\end{array}$ \\
\hline Sharma et al. [34] & $1990-2016$ & $\begin{array}{l}\text { Stock market, GDPPC, TO, } \\
\mathrm{RE} \text {, and technological } \\
\text { innovation }\end{array}$ & $\begin{array}{l}\text { South Asian } \\
\text { countries }\end{array}$ & CS-ARDL \\
\hline Fu et al. [35] & - & $\begin{array}{l}\mathrm{RE}, \mathrm{CO} 2 \text {, and economic } \\
\text { growth }\end{array}$ & BRICS countries & $\begin{array}{l}\text { "Cross-dependency" test, the unit root test, } \\
\text { and "CIPS" IPS, DOLS, and FMOLS }\end{array}$ \\
\hline Kula [36] & 1980-2008 & GDP and RE & OECD countries & $\begin{array}{l}\text { Pedroni cointegration tests, DOLS, and } \\
\text { VECM Granger causality test }\end{array}$ \\
\hline $\begin{array}{l}\text { Charfeddine and } \\
\text { Kahia [37] }\end{array}$ & $1980-2015$ & GDP, CO2, REC, LF, and FD & $\begin{array}{l}\text { Middle East and } \\
\text { North Africa, } 24 \\
\text { countries }\end{array}$ & $\begin{array}{l}\text { Panel VAR model and Westerlund ECM } \\
\text { panel cointegration test }\end{array}$ \\
\hline $\begin{array}{l}\text { Adewuyi and } \\
\text { Awodumi [38] }\end{array}$ & $1980-2010$ & $\begin{array}{c}\text { GDP, CO2, RE, FD, POP, and } \\
\text { TO }\end{array}$ & $\begin{array}{l}\text { West African } \\
\text { countries }\end{array}$ & Three-stage least squares (3SLS) \\
\hline Inglesi-Lotz [39] & 1990-2010 & GDP, RE, and LF & $\begin{array}{l}\text { OECD countries } \\
31 \text { OECD and } 49\end{array}$ & FE and panel cointegration test REC \\
\hline Cho et al. [40] & $1990-2010$ & GDP, RE, and LF & $\begin{array}{l}\text { non-OECD } \\
\text { countries }\end{array}$ & Panel VECM and FMOLS \\
\hline Dogan [41] & $1990-2012$ & GDP, REC, NRE, and LF & Turkey & $\begin{array}{l}\text { ARDL bounds test, Johansen panel } \\
\text { cointegration, and Gregory-Hansen } \\
\text { cointegration tests }\end{array}$ \\
\hline Shahbaz et al. [42] & 1972Q1-2011Q4 & $\begin{array}{l}\text { REC, LF, and capital } \\
\text { formation }\end{array}$ & Pakistan & $\begin{array}{c}\text { ARDL bounds test and VECM Granger } \\
\text { causality test }\end{array}$ \\
\hline
\end{tabular}

Source: author tabulation.

\section{Methodology}

3.1. Empirical Models and Variables. This study investigates the role of renewable and nonrenewable energy use in environmental quality for the period of 1970 to 2018 in 21 developing countries listed in Table 2. The nonrenewable energy sources used in this study are coal, oil, and natural gas, while the renewable energy sources used in this study are wind, solar, and hydropower, which are collected from BP statistics. Similarly, the study also used fossil fuel energy consumption collected from WDI (World Development Indicators) as a percentage of total final energy consumption and renewable energy consumption (percentage of total final energy consumption). Financial development is also used, expressed as a percentage of GDP in private sector domestic credit. The control variables used in the study are urban population and labor force.

The list of variables and data sources is shown in Table 3, and the conceptual model is shown in Figure 1. First, this study examines the impact of renewable energy sources and financial development on carbon emissions. Second, the study examines the impact of nonrenewable energy sources on carbon emissions. Next, we study the effects of the total renewable energy consumption and nonrenewable energy consumption in equations (3) and (4), respectively. The following models have been built:
TABLE 2: List of countries.

\begin{tabular}{lcc}
\hline Bangladesh & Iran Islamic Rep & Singapore \\
\hline Brazil & Iraq & South Africa \\
Chile & Israel & Sri Lanka \\
China & Pakistan & Turkey \\
Colombia & Philippines & United Arab Emirates \\
Ecuador & Qatar & Venezuela \\
Egypt Arab Rep. & Saudi Arabia & RB Vietnam \\
\hline
\end{tabular}

$$
\begin{aligned}
\mathrm{CO}_{2}= & \beta_{0}+\beta_{1} \mathrm{SLR}_{i t}+\beta_{2} \mathrm{HDR}_{i t}+\beta_{3} \mathrm{WND}_{i t} \\
& +\beta_{4} \mathrm{FD}+\beta_{5} \mathrm{UOP}+\beta_{6} \mathrm{LF}+\varepsilon_{i t}, \\
\mathrm{CO}_{2}= & \beta_{0}+\beta_{1} \mathrm{OL}_{i t}+\beta_{2} \mathrm{GS}_{i t}+\beta_{3} \mathrm{CL}_{i t} \\
& +\beta_{4} \mathrm{FD}+\beta_{5} \mathrm{UOP}+\beta_{6} \mathrm{LF}+\varepsilon_{i t}, \\
\mathrm{CO}_{2}= & \beta_{0}+\beta_{1} \mathrm{RET}_{i t}+\beta_{2} \mathrm{FD}_{i t}+\beta_{3} \mathrm{UOP}_{i t}+\beta_{4} \mathrm{LF}+\varepsilon_{i t}, \\
\mathrm{CO}_{2}= & \beta_{0}+\beta_{1} \mathrm{ENT}_{i t}+\beta_{2} \mathrm{FD}_{i t}+\beta_{3} \mathrm{UOP}_{i t}+\beta_{4} \mathrm{LF}+\varepsilon_{i t} .
\end{aligned}
$$

In above equations, carbon dioxide is represented by $\mathrm{CO}_{2}$ used for environmental degradation, SLR is solar energy, HDR is hydropower, WND is wind energy, FD is the financial development proxy by private sector domestic credit, RET is the total renewable energy consumption, ENT 
TABLE 3: Variables and data sources.

\begin{tabular}{lcrr}
\hline Variables & Symbols & & Data source \\
\hline Carbon emission & CO2 & & WDI \\
\hline Oil & OL & Nonrenewable energy sources & BP statistics \\
Coal & CL & & BP statistics \\
Natural gas & NG & BP statistics \\
\hline Hydroelectricity & HDR & Renewable energy sources & BP statistic \\
Solar energy & SLR & & BP statistics \\
Wind energy & WND & - & BP statistics \\
\hline Renewable energy consumption & RET & - & WDI \\
Nonrenewable energy consumption & NRT & - & WDI \\
Financial development & FD & - & WDI \\
Urban population & UP & - & WDI \\
Labor force & LF & WDI & \\
\hline
\end{tabular}

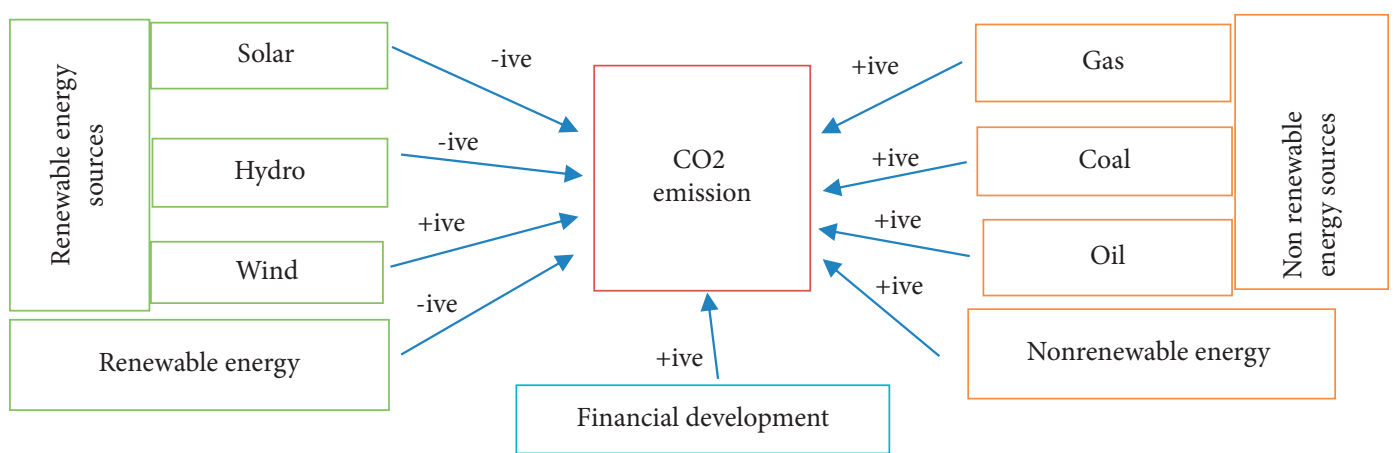

FIgURE 1: The impact of renewable and nonrenewable energy on carbon emission.

is nonrenewable energy, UOP is the urban population, LF is the labor force, and $\varepsilon$ is the error term.

3.2. Econometric Models. The current study explores the impact of energy sources and financial development on carbon emission. Three econometrics techniques were employed to the data which are OLS, fixed effect, and system GMM [49]. System GMM is the recent application concerning the theme; therefore, the current study is focusing on the object, and results are mostly concerned on this. In the first phase, the study has made the OLS and FE method estimation which is used for inspecting the issues of heterogeneity of countries. The GMM techniques are in the first difference and its permit taking to deal with the endogeneity problem concerned with variables of the study. System GMM has the ability to deal with the grouping of both difference and equations in the level. The instruments which specified for the difference equations are variables' delayed values in levels. Furthermore, the variables of the study are instrumented by the level equation and first differences. The system of the equations has been estimated by generalized method of moments simultaneously. The simulation about this of Monte Carlo made by Blundell and Bond [50] stated that SGMM model is efficient the most to estimate such issues. The overidentifying restriction tests are the Sargan test replaced as the Hansen test, and also, the serial correlation test of Arellano and Bond is used. Most of the results regarding these tests confirmed our study expectations. The Hansen test value gives the acceptance and shows the validity of the instruments. The serial correction tests shows whether the hypothesis is validated of second serial correlation of residuals. In the results of regression, the SD of coefficients is validated and heteroscedasticity problem has been checked. OLS and FE static models are employed along the SGMM model because to compare the results and check the robustness with preceding studies' outcomes; however, we especially focus on the system GMM results. The reason is that static models' results may not be efficient as these models may have several econometric issues, and the GMM model is considered the most efficient estimator. The equation for the system GMM model is given below:

$$
\mathrm{CO}_{2 i t}=\beta_{0}+\beta_{1} \mathrm{CO}_{2 i, t-1}+\beta_{2} Y_{i, t}+\beta_{3} X_{i, t}+\varepsilon_{i, t},
$$

where $\mathrm{CO}_{2}$ is carbon emission, $Y$ is the explanatory variable used in the study, $X$ represents the control variables, and $\mathrm{CO}_{2 i, t-1}$ is the lag of the dependent variable, while $\varepsilon$ is the error term.

\section{Findings and Discussions}

4.1. Renewable Energy Sources and Environmental Degradation. The lagged dependent variable is significant as given in Table 4, which validates the model fitness. AR2 and Sargan test also validate the instruments used in the model.

The impact of hydro energy on carbon emissions is significant at the level of $1 \%$ in the three measurements, and the impact on carbon emissions is negative. This shows that, in the sample of 21 developing countries, the increase in 
TABLE 4: The impact of renewable energy sources on carbon emission.

\begin{tabular}{lccc}
\hline Dependent variable: $\mathrm{CO}_{2}$ & OLS regression & Fixed effect & System GMM \\
\hline HDR (hydro energy) & $-1.970^{* * *}(0.247)$ & $-0.024^{* * *}(0.006)$ & $-0.007^{* * *}(0.001)$ \\
SLR (solar energy) & $-0.556^{* * *}(0.106)$ & $-0.256^{* *}(0.109)$ & $-0.181^{* * *}(0.013)$ \\
WND (wind energy) & $0.337^{*}(0.191)$ & $0.072(0.057)$ & $0.031^{* * *}(0.002)$ \\
FD (financial development) & $0.020^{* * *}(0.006)$ & $0.003(0.005)$ & $0.001^{* *}(0.0005)$ \\
UP (urban population) & $3.130^{* * *}(3.920)$ & $3.870(2.730)$ & $5.100^{* * *}(9.861)$ \\
LF (labor force) & $-1.350^{* * *}(2.320)$ & $-3.130^{* *}(1.512)$ & $-2.880^{* * *}(7.221)$ \\
CO 2 i,t-1 & - & - & $1.005^{* * *}(0.087)$ \\
Constant & $2.909^{* * *}$ & $60.48^{* *}$ & $0.000(0.000)$ \\
Obs & 43 & 59 & 506 \\
Number of id & - & 5 & 21 \\
$R$-squared & 0.937 & - & - \\
AR1 & - & - & $-2.937(0.008)$ \\
AR2 & - & - & $-1.67(0.094)$ \\
Sargan test & - & - & $859.20(0.000)$ \\
\hline
\end{tabular}

Note: ${ }^{* * *},{ }^{* *}$, and ${ }^{*}$ show the significance level at 1,5 , and 10 percent, respectively. Data source: BP statistics and WDI.

water energy reduces carbon emissions. More specifically, the results of the system GMM show that if hydropower is increased by 1 percentage point, carbon emissions will be reduced by 0.007 percentage points. The results confirmed that hydropower energy is beneficial to environmental quality, supports the theory of social choice, and confirms the theory of environmental degradation that human activities lead to environmental degradation. Countries still need to use the domestic new energy technology market to explore the field of renewable energy, but under current economic conditions, developing countries may not be able to obtain financial support for new technologies. It can be suggested that developing countries should promote and attract foreign investors who use green technologies in production. Similarly, solar energy is also very important as a source of renewable energy. The negative coefficient shows that it reduces carbon emissions and improves environmental quality. The results further show that if there is a unit change in solar energy, the carbon emissions will be reduced by $0.55,0.25$, and $0.18 \%$, respectively, indicated by OLS, FE, and system GMM. Solar energy is conducive to environmental quality and overcoming the energy crisis, especially in developing countries. Nowadays, some developing countries are facing energy crisis. They are trying to introduce solar energy for consumption, but they also need funds to obtain such technologies. Therefore, countries should also focus on economic development to overcome the energy crisis and protect the environment.

The estimated coefficient of wind energy on carbon emissions is significant, and its impact of carbon emissions is positive. The results show that due to the limited technology market in developing countries, the renewable energy sector, such as wind energy, may not be well developed. Alternative energy sources such as natural gas have also reduced attention to the development of the renewable energy sector because natural gas is easily used as an energy source, but natural gas consumption is harmful to the environment. Another reason may be that low-income countries may not be able to explore and fund renewable energy. The financial crisis has also reduced the level of investment and affected the exploration and development of the renewable energy sector. Technical standards lack of the reduction rate of renewable energy investment costs.

The estimated coefficient of domestic credit to the private sector (financial development) is highly significant and positive in OLS and system GMM, but not significant in the fixed effects' model. The results show that financial development has increased the carbon emissions of developing countries. The system GMM results show that a unit excess of domestic private sector credit will increase carbon emissions by $0.001 \%$. This is also determined by [51-56]. These differences may be due to different countries and different sample sizes.

Similarly, the urban population coefficient is significant and positive in the OLS regression and the system GMM model, indicating that the increase in urban population significantly increases carbon emissions. Urbanization is an important factor in increasing carbon emissions because as the population increases, the demand for transportation and energy increases, which in turn increases carbon emissions. Our results are consistent with the findings of Poumanyvong and Kaneko [57] but contrary to those of Rauf et al. [58]. Due to size and sample, results may vary. The labor force in the model shows that it reduces carbon emissions. The system GMM results show that, in the sample countries of developing countries, the percentage change in the labor force can reduce carbon emissions by $2.88 \%$.

4.2. Nonrenewable Energy Sources and Environmental Quality. Developing countries still rely mainly on nonrenewable energy use for production, such as coal, oil, and natural gas, which leads to environmental degradation. The results of the impact of nonrenewable energy on carbon emissions are shown in Table 5. Table 5 below shows the results of the Sargan test and AR2 correlation test, which support the effectiveness of the current research model tools. The estimated coefficient of coal as a nonrenewable energy source is positive and significant in all three models. The results showed that the use of coal energy increased the carbon emissions of the sample countries. More specifically, the system GMM results show that if there is a unit change in 
coal energy consumption, carbon emissions will increase by $0.005 \%$. The research results further show that coal energy is a nonrenewable energy source and is harmful to environmental quality. The result was supported by $[42,59,60]$.

The survey results further guide countries' policies to reduce carbon emissions by reducing the use of coal energy because coal will increase carbon dioxide emissions and enhance technologies that may help reduce environmental impact. Since our research sample is developing country rather than a developed country, it is still possible to use coal as an energy source, which is more harmful to the environment, but compared to using coal, using natural gas may be better because natural gas consumption may not be as bad as coal. The economic growth of these countries may not be conducive to the financing of renewable energy projects to obtain renewable energy, so it can be suggested that natural gas may be better than coal consumption, but in the future, these countries should strive to promote economic growth and invest in renewable energy to avoid the use nonrenewable energy sources such as coal and natural gas. Alkhathlan and Javid [61] also pointed out that compared with other nonrenewable energy sources, Saudi Arabia uses natural gas better, but the effect of coal on carbon emissions is the opposite. Similarly, the results of the natural gas coefficients in the three models are also significant, and the impact on carbon emissions is positive, indicating that the use of natural gas energy has an increasing impact on carbon emissions, leading to environmental degradation. The results of the system GMM model show that, for every $1 \%$ increase in natural gas energy use, the carbon emissions of the sample countries will increase by $0.001 \%$. However, it is believed that natural gas is much lower than other fossil fuels such as coal or oil.

Similarly, oil consumption as a nonrenewable energy source has a positive and significant impact on carbon emissions in all estimators. The results show that petroleum energy has increased the carbon emissions of the sample countries. From these results, it can be seen that oil is still used as the energy source in developing countries, which will indeed reduce the quality of the environment. Our results are consistent with the results of $[52,62,63]$.

In all estimates, financial development has a positive impact on carbon emissions. The research results show that financial development is the reason for the increase in carbon emissions in developing countries. The system GMM results show that, for every additional unit of credit in the private sector, carbon emissions will increase by $0.001 \%$, while the urban population coefficient is negatively correlated with carbon dioxide emissions. The labor force is positive and significant in OLS and FE, but the result is not significant and negative in the system GMM model, indicating that when labor is used as a control variable for the impact of nonrenewable energy on emissions, labor has no effect on carbon emissions.

4.3. Total Renewable Energy Consumption and Carbon Emission. Table 6 shows the results of the impact of renewable energy consumption on carbon emissions, where the RET estimation coefficient is negative and significantly confirms that it reduces carbon emissions. For example, a unit change of RET reduces carbon emissions by $0.38,0.31$, and 0.18 , respectively, shown by OLS, FE, and SGMM. Our research results support modern ecological theory, emphasizing that the increase in technology and innovation will improve environmental quality. Bilgili et al. [5] also pointed out that the use of renewable energy can improve environmental quality because it replaces traditional machinery and technologies that rely on fossil fuels. Compared with the use of traditional energy, the use of renewable energy will not cause a burden on the environment and sustainability and can also ensure energy security. Our research results are consistent with the results of Sharif et al. [13].They also proved that the impact of renewable energy consumption on carbon emissions is decreasing. Our research results are consistent with the claimed impact of renewable energy on carbon emissions $[13,64]$.

Similarly, the urban population coefficient is highly significant and positive in both the OLS regression and the system GMM model, indicating that the increase in urban population significantly increases carbon emissions, while it is negatively significant in the fixed effects model. The estimated coefficient of financial development is significant and positive in all models. The results show that financial development has increased carbon emissions in developing countries. System GMM results show that if domestic credit to the private sector increases by $1 \%$, it will increase carbon emissions by $0.183 \%$. The labor force in the OLS and system GMM models shows that it reduces carbon emissions. The system GMM results show that the percentage change in the labor force in developing countries reduces carbon emissions by $0.35 \%$, while the result in the fixed effects model is negative and significant.

\subsection{Total Nonrenewable Energy Consumption and Environ-} mental Degradation. Several researchers have debated that those developing countries are trying to increase economic growth and that is why these developing countries depend on nonrenewable energy to increase economic activities as these countries have not yet reached the level to fully use renewable energy for production in order to increase economic growth. The use of nonrenewable energy in these countries may lead to degradation of environment. For this purpose, to identify whether there exists the positive impact of nonrenewable energy used by these countries, we investigate this association, and the results are shown in Table 7 . The results indicates that the use of nonrenewable energy reduces the quality of environment by increasing carbon emission. For instance, the GMM results show that a percent increase in NRT causes an increase in emission by 1.26 percent. The results are in line with Table 4 findings, and they are also reinforced by the outcomes of Danish and Wang [65]. Previous studies have also shown that nonrenewable energy sources will reduce environmental quality by increasing carbon emissions. Most of the nonrenewable resources are used to promote economic growth in developing countries, which is the reason for the deterioration of the environment in these developing countries. The 
TABLE 5: The effect of nonrenewable energy sources on carbon emission.

\begin{tabular}{|c|c|c|c|}
\hline Dependent variable: $\mathrm{CO}_{2}$ & OLS regression & Fixed effect & System GMM \\
\hline CL (coal) & $0.001^{* *}(0.000)$ & $0.001^{* * *}(0.000)$ & $0.005^{*}(0.002)$ \\
\hline NG (natural gas) & $0.007^{* *}(0.003)$ & $0.004^{* * *}(0.000)$ & $0.001^{* *}(0.000)$ \\
\hline OL (oil) & $0.021^{* * *}(0.002)$ & $-0.002^{* *}(0.001)$ & $0.031^{* * *}(0.011)$ \\
\hline FD (financial development) & $0.011^{* * *}(0.001)$ & $0.005^{* * *}(0.000)$ & $0.001^{* *}(0.000)$ \\
\hline UP (urban population) & $-2.380^{* * *}(2.500)$ & $-6.430^{* *}(2.570)$ & $-0.025^{*}(0.015)$ \\
\hline LF (labor force) & $4.550^{* * *}(1.220)$ & $1.780^{* * *}(3.220)$ & $-0.006(0.013)$ \\
\hline Constant & $0.527^{* * *}(0.103)$ & $0.235^{* *}(0.093)$ & $0.496^{* * *}(0.187)$ \\
\hline $\mathrm{CO}_{2 i, t-1}$ & - & - & $0.954^{*}(0.011)$ \\
\hline Obs & 506 & 506 & 413 \\
\hline No. id & 21 & 21 & 18 \\
\hline$R^{2}$ & 0.378 & 0.413 & - \\
\hline AR1 & - & - & $-8.28(0.000)$ \\
\hline AR2 & - & - & $-1.60(0.109)$ \\
\hline Sargan test & - & - & $387.15(0.730)$ \\
\hline
\end{tabular}

Note: ${ }^{* * *},{ }^{* *}$, and ${ }^{*}$ show the significance level at 1,5 , and 10 percent, respectively. Data source: BP statistics and WDI.

TABLE 6: The effect of renewable energy consumption on carbon emission.

\begin{tabular}{lccc}
\hline Dependent variable: $\mathrm{CO}_{2}$ & OLS regression & Fixed effect & System GMM \\
\hline RET (renewable energy consumption) & $-0.387^{* * *}(0.013)$ & $-0.312^{* * *}(0.039)$ & $-0.183^{* * *}(0.046)$ \\
FD (financial development) & $0.013^{* * *}(0.000)$ & $0.005^{* * *}(0.000)$ & $0.200^{* * *}(0.022)$ \\
UOP (urban population) & $3.530^{* * *}(9.341)$ & $-7.971^{* *}(6.821)$ & $1.910^{* *}(7.111)$ \\
LF (labor force) & $-2.780^{* * *}(6.731)$ & $8.720^{* * *}(1.950)$ & $-0.357^{*}(0.189)$ \\
Constant & $1.185^{* * *}(0.059)$ & $0.964^{* * *}(0.130)$ & $0.000^{* * *}(0.000)$ \\
$\mathrm{CO}_{2 i, t-1}$ & - & - & $0.889^{* * *}(0.030)$ \\
Obs & 479 & 0.481 & 479 \\
$R^{2}$ & 0.712 & 20 & - \\
No. id & - & - & 20 \\
AR1 & - & - & $-1.45(0.147)$ \\
AR2 & - & - & $-0.92(0.357)$ \\
Sargan test & - & $426.46(0.950)$ \\
\hline
\end{tabular}

Note: ${ }^{* * *},{ }^{* *}$, and ${ }^{*}$ show the significance level at 1,5 , and 10 percent, respectively. Data source: BP statistics and WDI.

TABLE 7: Total nonrenewable energy consumption on carbon emission.

\begin{tabular}{lccc}
\hline Dependent variable: $\mathrm{CO}_{2}$ & OLS regression & Fixed effect & System GMM \\
\hline NRT (nonrenewable energy use) & $0.053^{* * *}(0.001)$ & $0.034^{* * *}(0.001)$ & $1.269^{* *}(0.607)$ \\
FD (financial development) & $0.007^{* * *}(0.001)$ & $0.002^{* * *}(0.000)$ & $0.085^{* * *}(0.025)$ \\
UP (urban population) & $2.490^{* *}(9.771)$ & $1.630^{* * *}(5.721)$ & $3.720^{* * *}(2.750)$ \\
LF (labor force) & $-2.460^{* * *}(7.031)$ & $7.791(1.690)$ & $-0.961^{* * *}(0.301)$ \\
Constant & $-3.456^{* * *}(0.134)$ & $-1.831^{* * *}(0.135)$ & $0.000^{* * *}(0.000)$ \\
CO $_{2 i, t-1}$ & - & - & $1.028(0.031)$ \\
Observations & 493 & 493 & 493 \\
$R^{2}$ & 0.726 & -638 & - \\
No. id & - & - & 21 \\
AR1 & - & - & $-1.62(0.105)$ \\
AR2 & - & - & $-1.26(0.209)$ \\
Sargan test & - & - & $646.50(0.000)$ \\
\hline
\end{tabular}

Note: ${ }^{* * *},{ }^{* *}$, and ${ }^{*}$ show the significance level at 1,5 , and 10 percent, respectively. Data source: BP statistics and WDI.

governments of these developing countries should take measures to diversify energy supply to meet demand and promote and attract foreign investors to provide funds and technologies for green production.

The results on the impact of financial development on carbon emission are also significant and positive, which indicates its increase in emission in the sample countries. This result also matches Table 4 results. For instance, the GMM system model shows that a percent increase in financial development increases carbon emission by 0.08 percent in the sample countries.

Urban population is also positive and significant which also increases carbon emission, while labor forces are negative. Its means that a percentage change in the labor force reduces the carbon emissions of developing countries by 0.9 percent. 
TABLE 8: Summary of results.

\begin{tabular}{lccccc}
\hline Variables & RE & $\begin{array}{c}\text { RE } \\
\text { sources }\end{array}$ & Variables & NRE & NRE sources \\
\hline RE & - sign & - & NRE & + sig & - \\
HDR & - & - sign & CL & - & + sig \\
SLR & - & - sign & NG & - & + sig \\
WND & - & + sig & OL & - & + sig \\
FD & + sig & + sig & FD & + sig & + sig \\
UP & + sig & + sig & UP & + sig & - sig \\
LF & - sig & - sig & LF & - sig & - sig \\
\hline
\end{tabular}

Note: + sig and - sig show positive and negative significant, respectively.

\section{Conclusion and Policy Implication}

This study uses data from 21 developing countries downloaded from WDI and BP statistics from 1970 to 2018 to examine the impact of energy consumption on carbon emissions. By adopting the OLS model and fixed effects and dynamic system GMM, the research results show the significant negative effect of renewable energy and its sources on carbon emissions means that it has improved the environmental quality of 21 developing countries. On the contrary, in Model 2 and Model 4, the impact of nonrenewable energy and its sources, including oil, natural gas, and coal, has a positive impact on carbon emissions, indicating that it has an increasing impact on carbon emissions in developing countries and the environmental quality has declined. It is found in all models that financial development is positive, which indicates that financial development will increase carbon emissions. The results of various indicators are summarized in Table 8 , showing the positive and negative impacts of indicators on carbon emissions.

The results of the survey guide countries to formulate policies to reduce carbon emissions by reducing the use of fossil fuel energy sources such as coal, oil, and natural gas, as this will increase carbon dioxide emissions and to develop technologies that may help reduce environmental impact. Since our research sample is a developing country rather than a developed country, they may still use fossil fuels such as coal, oil, and natural gas to meet the more environmentally unfavorable energy needs, but compared to coal, it may be better to use natural gas because compared with coal, natural gas consumption may not be too harmful. The economic growth of these countries may not be conducive to financing renewable energy projects to obtain renewable energy, so it can be suggested that natural gas may be better than coal consumption, but in the future, these countries should strive to promote economic growth and invest in renewable energy to avoid the use of nonrenewable energy sources, such as coal and natural gas.

The governments of these developing countries must call for high-level initiatives to diversify energy supply to meet growing demand of energy and promote the attraction of foreign investors who provide green production technologies and capital. By doing so, renewable energy will be used, which will help reduce emissions and help promote economic growth. In developing countries, nonrenewable energy is used as fuel for industrial production and household consumption. Therefore, it is recommended to switch to renewable energy sources that have minimal or no environmental impact. Policy makers should adopt policies and encourage environmentally-friendly equipment, vehicles, and utilization to minimize environmental degradation in developing countries. The use of nonrenewable energy is harmful to the quality of the environment, and developing countries use this energy to promote economic activities that lead to carbon emissions and environmental degradation. Obviously, developing countries continue to focus on promoting economic growth. They are using energy to increase production and promote economic growth, and the use of energy consumption has increased the level of carbon emissions in these countries. Compared with the environmental quality of developed countries, developing countries have more serious pollution.

Most researchers found that the degree of environmental degradation in developed countries is low because these countries use renewable energy and the quality of institutions in these countries is better. This is also the reason for the harmful effects of environmental quality protection and other factors on environmental quality if they use nonrenewable energy. Our research results conclude that nonrenewable energy is mainly used in developing countries to promote economic growth. At the same time, we also believe that this effect may be different in different countries such as developing and developed countries. For developing countries, while focusing on promoting economic growth, it is important not to ignore the environmental impact of using nonrenewable resources. In the future, research on the same topic should be conducted on different samples to compare these findings. Future research may also include institutional quality variables and test environmental Kuznets curve. Developing countries focus on improving economic growth by using nonrenewable energy to understand whether economic growth will improve environmental quality when income reaches a certain level.

\section{Data Availability}

The data used in this article can be obtained from the World Bank World Development Indicators and BP Statistics. The WDI link is https://databank.worldbank.org/source/worlddevelopment-indicators.

\section{Conflicts of Interest}

The authors declare that there are no conflicts of interest regarding the publication of this article.

\section{References}

[1] H. M. A. Siddique and M. T. Majeed, "Energy consumption, economic growth, trade and financial development nexus in South Asia," Pakistan Journal of Commerce and Social Sciences (PJCSS), vol. 9, no. 2, pp. 658-682, 2015.

[2] H. M. A. Siddique, "Impact of financial development and energy consumption on $\mathrm{CO}_{2}$ emissions: evidence from Pakistan," Bulletin of Business and Economics, vol. 6, no. 2, pp. 68-73, 2017. 
[3] Y. Wolde-Rufael and K. Menyah, "Nuclear energy consumption and economic growth in nine developed countries," Energy Economics, vol. 32, no. 3, pp. 550-556, 2010.

[4] A. K. Akella, R. P. Saini, and M. P. Sharma, "Social, economical and environmental impacts of renewable energy systems," Renewable Energy, vol. 34, no. 2, pp. 390-396, 2009.

[5] F. Bilgili, E. Koçak, and Ü. Bulut, "The dynamic impact of renewable energy consumption on $\mathrm{CO}_{2}$ emissions: a revisited Environmental Kuznets Curve approach," Renewable and Sustainable Energy Reviews, vol. 54, pp. 838-845, 2016.

[6] M. B. Jebli and S. B. Youssef, "Renewable energy consumption and agriculture: evidence for cointegration and Granger causality for Tunisian economy," The International Journal of Sustainable Development and World Ecology, vol. 24, no. 2, pp. 149-158, 2017.

[7] D. Balsalobre-Lorente, M. Shahbaz, D. Roubaud, and S. Farhani, "How economic growth, renewable electricity and natural resources contribute to $\mathrm{CO}_{2}$ emissions?" Energy Policy, vol. 113, pp. 356-367, 2018.

[8] E. Dogan and I. Ozturk, "The influence of renewable and nonrenewable energy consumption and real income on $\mathrm{CO}_{2}$ emissions in the USA: evidence from structural break tests," Environmental Science and Pollution Research, vol. 24, no. 11, pp. 10846-10854, 2017.

[9] K. Ito, " $\mathrm{CO}_{2}$ emissions, renewable and non-renewable energy consumption, and economic growth: evidence from panel data for developing countries," International Economics, vol. 151, pp. 1-6, 2017.

[10] M. Kahia, M. B. Jebli, and M. Belloumi, "Analysis of the impact of renewable energy consumption and economic growth on carbon dioxide emissions in 12 MENA countries," Clean Technologies and Environmental Policy, vol. 21, no. 4, pp. 871-885, 2019.

[11] H. Khan, I. Khan, and T. T. Binh, "The heterogeneity of renewable energy consumption, carbon emission and financial development in the globe: a panel quantile regression approach," Energy Report, vol. 6, pp. 859-867, 2020.

[12] B. Saboori and J. Sulaiman, "Environmental degradation, economic growth and energy consumption: evidence of the environmental Kuznets curve in Malaysia," Energy Policy, vol. 60, pp. 892-905, 2013.

[13] A. Sharif, S. A. Raza, I. Ozturk, and S. Afshan, "The dynamic relationship of renewable and nonrenewable energy consumption with carbon emission: a global study with the application of heterogeneous panel estimations," Renewable Energy, vol. 133, pp. 685-691, 2019.

[14] N. Apergis and J. E. Payne, "Renewable energy, output, carbon dioxide emissions, and oil prices: evidence from South America," Energy Sources, Part B: Economics, Planning, and Policy, vol. 10, no. 3, pp. 281-287, 2015.

[15] G. Bölük and M. Mert, "Fossil \& renewable energy consumption, GHGs (greenhouse gases) and economic growth: evidence from a panel of EU (European Union) countries," Energy, vol. 74, pp. 439-446, 2014.

[16] M. B. Jebli and S. B. Youssef, "The role of renewable energy and agriculture in reducing $\mathrm{CO}_{2}$ emissions: evidence for North Africa countries," Ecological Indicators, vol. 74, pp. 295-301, 2017.

[17] U. Al-Mulali, I. Ozturk, and H. H. Lean, "The influence of economic growth, urbanization, trade openness, financial development, and renewable energy on pollution in Europe," Natural Hazards, vol. 79, no. 1, pp. 621-644, 2015.

[18] S. A. H. Zaidi, Danish, F. Hou, and F. M. Mirza, "The role of renewable and non-renewable energy consumption in $\mathrm{CO}_{2}$ emissions: a disaggregate analysis of Pakistan," Environmental Science and Pollution Research, vol. 25, no. 31, pp. 3161631629, 2018.

[19] I. Hanif, "Impact of economic growth, nonrenewable and renewable energy consumption, and urbanization on carbon emissions in Sub-Saharan Africa," Environmental Science and Pollution Research, vol. 25, no. 15, pp. 15057-15067, 2018.

[20] O. B. Awodumi and A. O. Adewuyi, "The role of non-renewable energy consumption in economic growth and carbon emission: evidence from oil producing economies in Africa," Energy Strategy Reviews, vol. 27, Article ID 100434, 2020.

[21] M. K. Khan, M. I. Khan, and M. Rehan, "The relationship between energy consumption, economic growth and carbon dioxide emissions in Pakistan," Financial Innovation, vol. 6, no. 1, pp. 1-13, 2020.

[22] C. Işık, S. Ongan, and D. Özdemir, "Testing the EKC hypothesis for ten US states: an application of heterogeneous panel estimation method," Environmental Science and Pollution Research International, vol. 26, no. 11, pp. 10846-10853, 2019.

[23] M. K. Anser, I. Hanif, M. Alharthi, and I. S. Chaudhry, "Impact of fossil fuels, renewable energy consumption and industrial growth on carbon emissions in Latin American and Caribbean economies," Atmósfera, vol. 33, no. 3, pp. 201-213, 2020.

[24] W. Zhao, R. Zhong, S. Sohail, M. T. Majeed, and S. Ullah, "Geopolitical risks, energy consumption, and $\mathrm{CO}_{2}$ emissions in BRICS: an asymmetric analysis," Environmental Science and Pollution Research, vol. 28, pp. 39668-39679, 2021.

[25] M. S. Karimi, S. Ahmad, H. Karamelikli et al., "Dynamic linkages between renewable energy, carbon emissions and economic growth through nonlinear ARDL approach: evidence from Iran," PLoS One, vol. 16, no. 7, Article ID e0253464, 2021.

[26] L. Yuping, M. Ramzan, L. Xincheng et al., "Determinants of carbon emissions in Argentina: the roles of renewable energy consumption and globalization," Energy Report, vol. 7, pp. 4747-4760, 2021.

[27] M. T. Majeed and T. Luni, "Renewable energy, water, and environmental degradation: a global panel data approach," Pakistan Journal of Commerce and Social Sciences (PJCSS), vol. 13, no. 3, pp. 749-778, 2019.

[28] H. Khan, L. Weili, I. Khan, and S. Khamphengxay, "Renewable energy consumption, trade openness, and environmental degradation: a panel data analysis of developing and developed countries," Mathematical Problems in Engineering, vol. 2021, Article ID 6691046, 2021.

[29] R. Inglesi-Lotz and E. Dogan, "The role of renewable versus non-renewable energy to the level of $\mathrm{CO}_{2}$ emissions a panel analysis of sub- Saharan Africa's big 10 electricity generators," Renewable Energy, vol. 123, pp. 36-43, 2018.

[30] H. Ali, H. M. A. Siddique, K. Ullah, and M. T. Mahmood, "Human capital and economic growth nexus in Pakistan: the role of foreign aid," Bulletin of Business and Economics, vol. 7, no. 1, pp. 13-21, 2018.

[31] H. Alqaralleh, "On the nexus of $\mathrm{CO}_{2}$ emissions and renewable and nonrenewable energy consumption in Europe: a new insight from panel smooth transition," Energy \& Environment, vol. 32, no. 3, pp. 443-457, 2021.

[32] T. Fatima, U. Shahzad, and L. Cui, "Renewable and nonrenewable energy consumption, trade and $\mathrm{CO}_{2}$ emissions in high emitter countries: does the income level matter?" Journal of Environmental Planning and Management, vol. 64, no. 7, pp. 1227-1251, 2021. 
[33] R. L. Ibrahim and K. B. Ajide, "Disaggregated environmental impacts of non-renewable energy and trade openness in selected G-20 countries: the conditioning role of technological innovation," Environmental Science and Pollution Research, pp. 1-15, 2021.

[34] R. Sharma, M. Shahbaz, A. Sinha, and X. V. Vo, "Examining the temporal impact of stock market development on carbon intensity: evidence from South Asian countries," Journal of Environmental Management, vol. 297, Article ID 113248, 2021.

[35] Q. Fu, S. Álvarez-Otero, M. S. Sial et al., "Impact of renewable energy on economic growth and $\mathrm{CO} 2$ emissions-evidence from BRICS countries," Processes, vol. 9, no. 8, p. 1281, 2021.

[36] F. Kula, "The long-run relationship between renewable electricity consumption and GDP: evidence from panel data," Energy Sources, Part B: Economics, Planning, and Policy, vol. 9, no. 2, pp. 156-160, 2014.

[37] L. Charfeddine and M. Kahia, "Impact of renewable energy consumption and financial development on $\mathrm{CO}_{2}$ emissions and economic growth in the MENA region: a panel vector autoregressive (PVAR) analysis," Renewable Energy, vol. 139, pp. 198-213, 2019.

[38] A. O. Adewuyi and O. B. Awodumi, "Renewable and nonrenewable energy-growth-emissions linkages: review of emerging trends with policy implications," Renewable and Sustainable Energy Reviews, vol. 69, pp. 275-291, 2017.

[39] R. Inglesi-Lotz, “The impact of renewable energy consumption to economic growth: a panel data application," Energy Economics, vol. 53, pp. 58-63, 2016.

[40] S. Cho, E. Heo, and J. Kim, "Causal relationship between renewable energy consumption and economic growth: comparison between developed and less-developed countries," Geosystem Engineering, vol. 18, no. 6, pp. 284-291, 2015.

[41] E. Dogan, "The relationship between economic growth and electricity consumption from renewable and non-renewable sources: a study of Turkey," Renewable and Sustainable Energy Reviews, vol. 52, pp. 534-546, 2015.

[42] M. Shahbaz, N. Loganathan, M. Zeshan, and K. Zaman, "Does renewable energy consumption add in economic growth? An application of auto-regressive distributed lag model in Pakistan," Renewable and Sustainable Energy Reviews, vol. 44, pp. 576-585, 2015.

[43] H. Khan, I. Khan, L. T. Kim Oanh, and Z. Lin, "The dynamic interrelationship of environmental factors and foreign direct investment: dynamic panel data analysis and new evidence from the globe," Mathematical Problems in Engineering, vol. 2020, Article ID 2812489, 12 pages, 2020.

[44] H. Khan, M. S. Jan, J. Hu, and C. I. Khan, "Impact of governance on foreign direct investment in context of Pakistan," Journal of International Finance and Economics, vol. 19, no. 1, pp. 53-64, 2019.

[45] M. Cetin, E. Ecevit, and A. G. Yucel, "The impact of economic growth, energy consumption, trade openness, and financial development on carbon emissions: empirical evidence from Turkey," Environmental Science and Pollution Research, vol. 25, no. 36, pp. 36589-36603, 2018.

[46] H. Khan, L. Weili, and I. Khan, "Environmental innovation, trade openness and quality institutions: an integrated investigation about environmental sustainability," Environment, Development and Sustainability, pp. 1-31, 2021.

[47] J. A. Bhat, "Renewable and non-renewable energy consumption-impact on economic growth and $\mathrm{CO}_{2}$ emissions in five emerging market economies," Environmental Science and Pollution Research, vol. 25, no. 35, pp. 35515-35530, 2018.
[48] H. Khan, L. Weili, I. Khan, and L. T. Kim Oanh, "Recent advances in energy usage and environmental degradation: does quality institutions matter? a worldwide evidence," Energy Report, vol. 7, pp. 1091-1103, 2021.

[49] Blundell, R., \& Bond, S. (1995). On the Use of Initial Conditions in Dynamic Panel Data Models. Retrieved from.

[50] R. Blundell and S. Bond, "Initial conditions and moment restrictions in dynamic panel data models," Journal of Econometrics, vol. 87, no. 1, pp. 115-143, 1998.

[51] M. A. Boutabba, "The impact of financial development, income, energy and trade on carbon emissions: evidence from the Indian economy," Economic Modelling, vol. 40, pp. 33-41, 2014.

[52] E. Dogan and F. Seker, "The influence of real output, renewable and non-renewable energy, trade and financial development on carbon emissions in the top renewable energy countries," Renewable and Sustainable Energy Reviews, vol. 60, pp. 1074-1085, 2016.

[53] A. Jalil and M. Feridun, "The impact of growth, energy and financial development on the environment in China: a cointegration analysis," Energy Economics, vol. 33, no. 2, pp. 284-291, 2011.

[54] T.-H. Le, "Dynamics between energy, output, openness and financial development in sub-Saharan African countries," Applied Economics, vol. 48, no. 10, pp. 914-933, 2016.

[55] I. Ozturk and A. Acaravci, "The long-run and causal analysis of energy, growth, openness and financial development on carbon emissions in Turkey," Energy Economics, vol. 36, pp. 262-267, 2013.

[56] M. Shahbaz, Z. Mushtaq, F. Andaz, and A. Masood, "Does proline application ameliorate adverse effects of salt stress on growth, ions and photosynthetic ability of eggplant (Solanum melongena L.)?" Scientia Horticulturae, vol. 164, pp. 507-511, 2013.

[57] P. Poumanyvong and S. Kaneko, "Does urbanization lead to less energy use and lower $\mathrm{CO}_{2}$ emissions? a cross-country analysis," Ecological Economics, vol. 70, no. 2, pp. 434-444, 2010.

[58] A. Rauf, X. Liu, W. Amin et al., "Does sustainable growth, energy consumption and environment challenges matter for Belt and Road Initiative feat? a novel empirical investigation," Journal of Cleaner Production, vol. 262, Article ID 121344, 2020.

[59] M. W. Ahmad, M. Mourshed, D. Mundow, M. Sisinni, and Y. Rezgui, "Building energy metering and environmental monitoring - a state-of-the-art review and directions for future research," Energy and Buildings, vol. 120, pp. 85-102, 2016.

[60] O. Mohiuddin, S. Asumadu-Sarkodie, and M. Obaidullah, "The relationship between carbon dioxide emissions, energy consumption, and GDP: a recent evidence from Pakistan," Cogent Engineering, vol. 3, no. 1, Article ID 1210491, 2016.

[61] K. Alkhathlan and M. Javid, "Carbon emissions and oil consumption in Saudi Arabia," Renewable and Sustainable Energy Reviews, vol. 48, pp. 105-111, 2015.

[62] M. B. Jebli, S. B. Youssef, and I. Ozturk, "Testing environmental Kuznets curve hypothesis: the role of renewable and non-renewable energy consumption and trade in OECD countries," Ecological Indicators, vol. 60, pp. 824-831, 2016.

[63] M. Shahbaz, G. S. Uddin, I. U. Rehman, and K. Imran, "Industrialization, electricity consumption and $\mathrm{CO}_{2}$ emissions in Bangladesh," Renewable and Sustainable Energy Reviews, vol. 31, pp. 575-586, 2014. 
[64] S. Farhani and M. Shahbaz, "What role of renewable and nonrenewable electricity consumption and output is needed to initially mitigate $\mathrm{CO}_{2}$ emissions in MENA region?" Renewable and Sustainable Energy Reviews, vol. 40, pp. 80-90, 2014.

[65] Danish and Z. Wang, "Dynamic relationship between tourism, economic growth, and environmental quality," Journal of Sustainable Tourism, vol. 26, no. 11, pp. 1928-1943, 2018. 